\title{
Abundance and Adaptation Level of Some Soil Microbes in Salt-affected Soils
}

\author{
B. BIRÓ, I. VILLÁNYI and K. KÖVES-PÉCHY \\ Research Institute for Soil Science and Agricultural Chemistry (RISSAC) of the \\ Hungarian Academy of Sciences, Budapest
}

Salt-affected soils cover roughly $10 \%$ of the surface of the continents (SZABOLCS, 1998). More than a hundred countries have salt-affected soils, occupying different proportions of their territory. Depending on the type of the salts, however, these soils can be very diverse in their appearance, morphology and in some other characteristics, which can greatly limit their fertility (SZABOLCS \& VÁRALLYAY, 1978). The soil, in general, is said to be saline if the conductivity exceeds $4 \mathrm{dS} \mathrm{m}^{-1}$ or the concentration of salts is higher than $0.1 \%$ (JUNIPER \& ABBOTT, 1993).

On saline or sodic areas both the macro-biota (halophytes) and the microbiota (rhizosphere components) are usually specially adapted to the particular stress conditions. These functional interactions between the two partners can reduce the rate of the environmental stress, such as the negative osmotic pressure, imbalance of essential elements, toxicity of salt-specific ions, unfavourable pH (HASEGAWA et al., 1986; BIRÓ et al., 2000). Several bacterial or fungal representatives of the salt-adapted micro- or rhizobiota can tolerate more than $4-30 \%$ of $\mathrm{NaCl}$ concentrations (ZAHRAN, 1997). Adaptation is a complex phenomenon, where the plant physiological status (i.e. respiration) and, as a consequence, the rhizosphere components also change continuously (SCHWARZ $\&$ GALE, 1984). Interaction developed between the halophytes and the microbes can be specific enough for characterizing the soil quality or fertility (RUIZLOZANO et al., 1996). The establishment of the abundance of the main microbial groups is the first step of such soil indications (HASEGAWA et al., 1986). There are relatively few data, however, about the microbial abundance, versatility and functioning of these naturally salt-affected soils.

The total number and relative proportion of salt-tolerant (adapted) microbes of the most dominant halophytes were determined in this study from two se-

Correspondence to: Dr. Borbála BIRÓ, Research Institute for Soil Science and Agricultural Chemistry (RISSAC) of the Hungarian Academy of Sciences, H-1022 Budapest, Herman Ottó út 15. Hungary. E-mail: biro@rissac.hu 
lected salt-affected sites of the Hortobágy region (Hungary). By using a modified plate counting method the abundance and variability (colony types) of some culturable rhizosphere constituents, such as the Actinomycetes, nitrogen fixers, micromycetes (microscopic fungi), pseudomonads were investigated at increasing salinity levels in vitro.

\section{Materials and Methods}

Soil samples were collected from the rhizosphere of dominant halophytes at

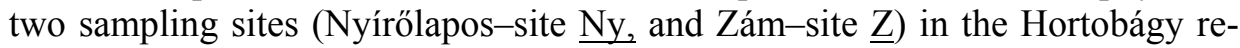
gion (Hungary). Site characterization was accomplished by the classical soil physical, chemical and microbiological parameters. The salt concentration and $\mathrm{Cl}^{-}$ion content was measured by conductivity, and the concentration of most important salt-specific ions was determined, as well as soil $\mathrm{pH}$.

Abundance of some culturable soil microbiological groups, such as Actinomycetes, total number of bacteria, free living $\mathrm{N}_{2}$ fixers, micromycetes and pseudomonads were estimated by the classical plate counting procedure on selective media (with some technical modifications developed in an earlier study - ANGERER et al., 1998). A 10-fold dilution series was made from the rhizosphere soils of the dominant halophytes (FÜZY et al., 2001) from both sites. Selective plates, such as the Nutrient, King-B, Martin, Starch-Casein, Ashby were used for the total number of microbes, the fluorescens-putida type pseudomonads, the micromycetes, the Actynomycetes and the free living $\mathrm{N}_{2}$-fixers, respectively (HORVÁTH, 1980; KING et al., 1954; MARTIN, 1950; WILLIAMS \& DAVIES, 1964; SZEGI, 1979). Plates were incubated at $26^{\circ} \mathrm{C}$ for 24,48 or 72 hours, as a function of the microbial groups. Different amounts of salt $(0,5,10$ and $50 \mathrm{~g} \mathrm{l}^{-1} \mathrm{NaCl}$ ) were added to the selective media for testing the salt tolerance limits, and the ratio of adapted microorganisms according to their origin. Total number of colony forming units (CFU g ${ }^{-1}$ dry soil) and the colony types were determined at increasing salt stress in vitro.

\section{Results}

\section{Main soil characteristics of the sampling sites}

The selected sites of the salt-affected Hortobagy region (Hungary) had common and different soil properties. According to the soil physical survey, similar characteristics were found at both sites. Soil chemical features, however, rather differed. The $\mathrm{pH}$ at Nyírölapos (site Ny) was between 6.10 and 9.73, while at Zám (site Z) it ranged from 5.76 to 6.38. A more versatile abundance of salt specific anions was found at Site Ny. Dominance of the main anions is also different at the two sites: at Nyírölapos mainly the $\mathrm{Na}_{2} \mathrm{SO}_{4}$, while at Zám the $\mathrm{NaCl}$ 
salt types were more frequent, with an amount of about $80 \%$ within the total salt content. Comparing these soil chemical properties in the two soil samples, a more stressed situation was found at the Nyírollapos site, due to the higher electric conductivity and $\mathrm{pH}$ levels. Further details on soil properties were reported by FÜZY et al. (2001).

\section{The number of culturable bacteria at the two sampling sites}

A $\log _{10}$ counted abundance (colony forming units - CFU g ${ }^{-1}$ dry soil) of the selected microbial groups is demonstrated in Figure 1. Numbers of culturable microbes on the different saline and selecting media $\left(0,10\right.$ and $\left.50 \mathrm{~g} \mathrm{l}^{-1}\right)$ were estimated after appropriate incubation. Reduction of abundance was found mainly at higher salt levels. The most sensitive group was the free living nitrogen fixers, where a slight reduction (one-fold level at site $\mathrm{Z}$ ) was determined at $10 \mathrm{~g} \mathrm{l}^{-1} \mathrm{NaCl}$ concentration. The salt tolerance of microbes originating from the two sampling sites is rather variable: the reduction in total number was more expressed in samples from Site Z, but in case of microfungi those originating from Site Ny were more sensitive; a similar reduction could be detected for the Actinomycetes. The higher fungal dominance at Site $\mathrm{Z}$ is considered to be a consequence of the more acidic conditions, which promotes fungal populations. Siderophore producing, fluorescens-putida type Pseudomonas bacteria on the other hand were found to be more frequent under the more saline (more stressed) conditions.

The versatility of micromycetes plotted against the increasing salt concentrations

Four samples from the two sampling sites with four different salinity levels were studied for the number of colony types at different in vitro salt concentrations $\left(0,5,10\right.$ and $\left.50 \mathrm{~g}^{-1} \mathrm{NaCl}\right)$. The four samples showed a similar tendency (Figure 2) in the versatility of the colonies: a slight increase up till the $5 \mathrm{~g}$ $\mathrm{I}^{-1}$ level of salt concentration (samples from site $\mathrm{Ny}$ ) or $10 \mathrm{~g} \mathrm{l}^{-1}$ (samples from site Z). A significant decrease was found, however above these concentrations. The highest variation of colonies is between 4 and 8 , with the exception of the most saline $\left(\mathrm{EC}=20.05 \mathrm{dS} \mathrm{m}^{-1}\right)$ soils, where the selection of salt stress proved to be more serious. In these highly saline soils only one colony type was found among the microscopic fungi. The decrease in such microbial diversity colony types can be seen in Figure 2 as a function of the increasing salt concentrations in vitro. 


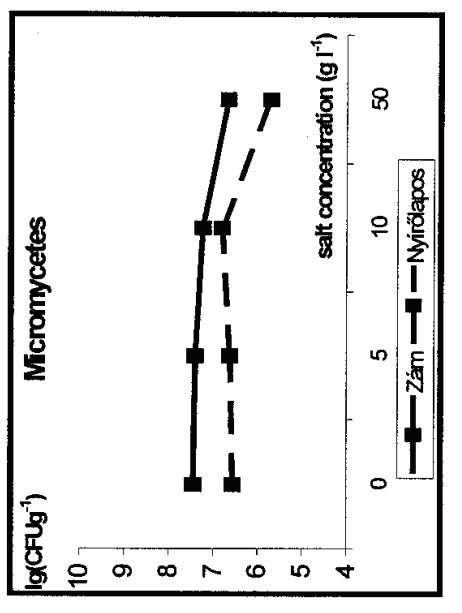

궁휴 흔

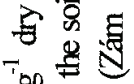

俤总。

总窟窘

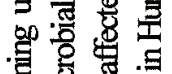

石兽若

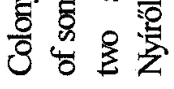

$\ddot{\circ}$
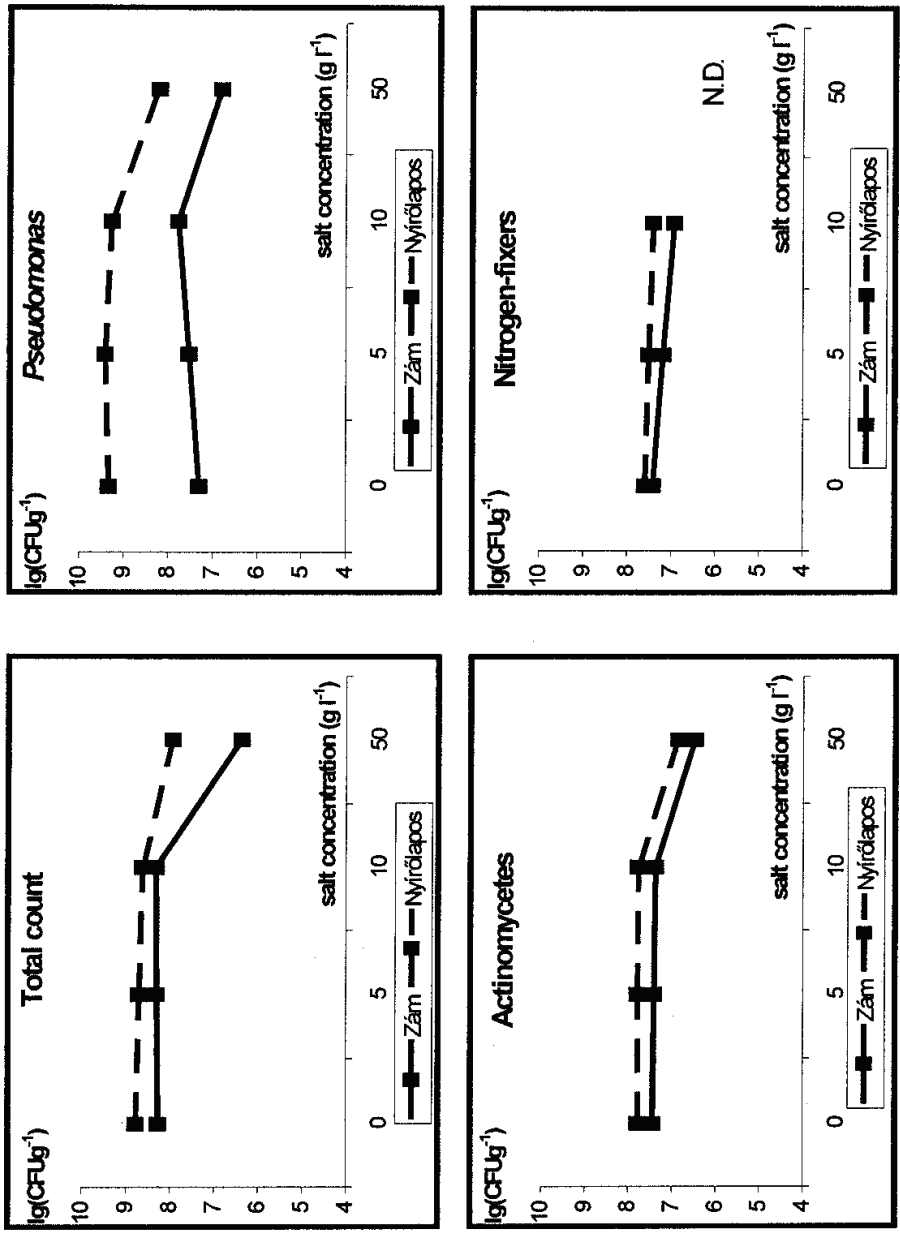

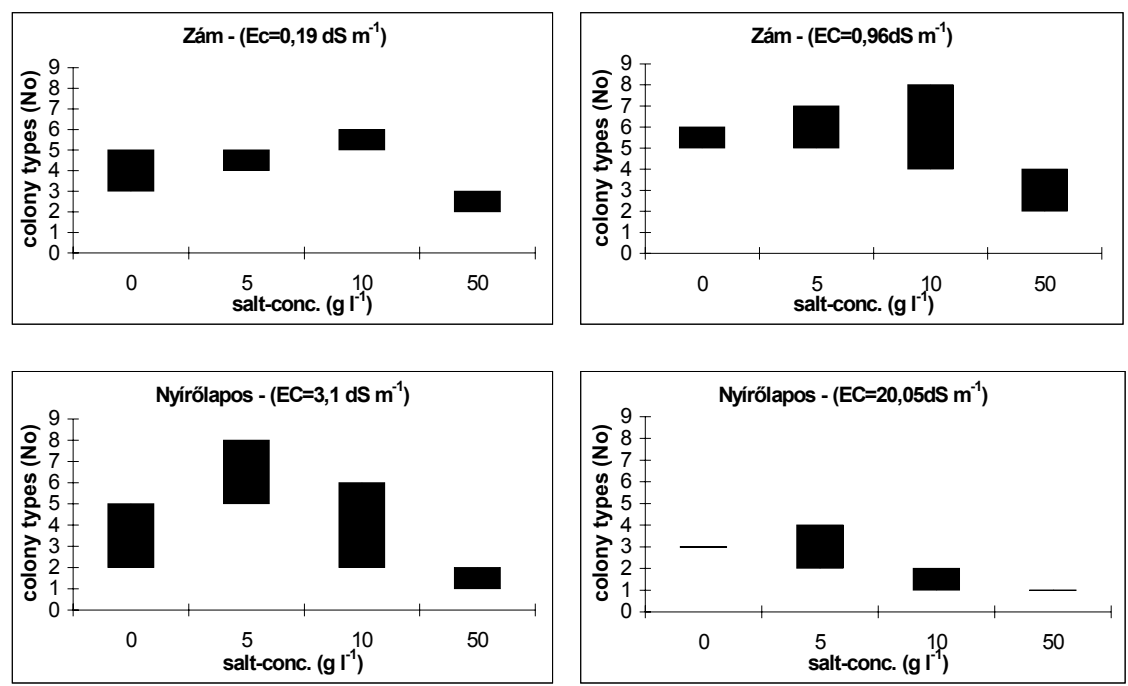

Fig. 2: Colony types of the micromycetes in two salt affected soils of the Hortobágy region (Hungary). Note the decreased number of the adapted species as a function of the increasing salt concentrations in vitro and the original sodic conditions (low and high) of the two sites (Zám and Nyírölapos).

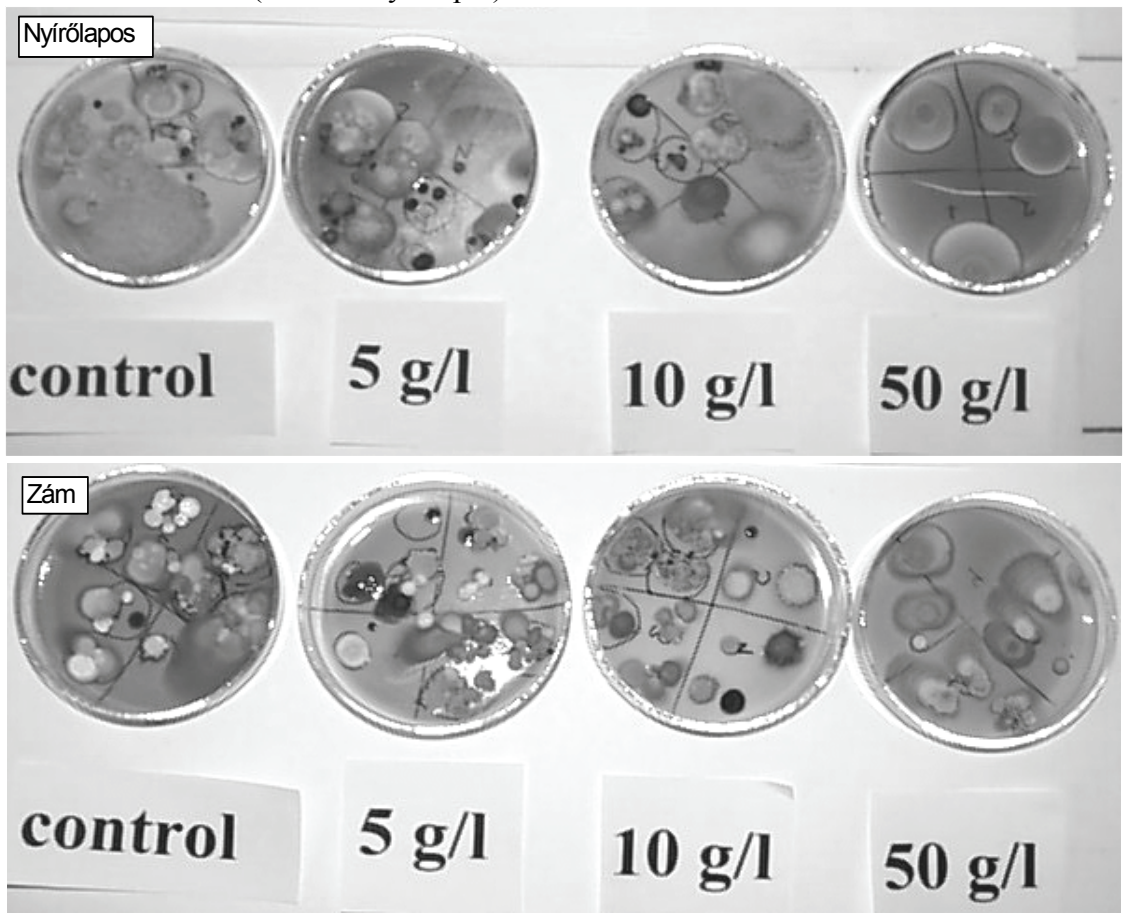




\section{Discussion}

$1 \%$ salt $(\mathrm{NaCl})$ in the media had no effect or slightly stimulated the abundance of the culturable microbial groups. Free living nitrogen fixing microbes however were significantly reduced in their number at the lower salt concentrations (Figure 1). Nitrogen fixers therefore seem to be the microbes most sensitive to salt stress, which is in agreement with some earlier findings (SCHWARZ \& GALE, 1984; BIRÓ et al., 1999). At the $5 \%\left(50 \mathrm{~g} \mathrm{l}^{-1}\right)$ salt concentration, a onefold reduction could be observed in case of all microbial groups investigated. A two-fold decrease was detected in the total count of microbes in samples from Zám (site Z). The number of colony types of micromycetes was also monitored in four soil samples. These originated from two different salinity levels at each sampling site (Figure 2). Differences could be found as a function of the main characteristics, such as soil salt concentrations. Factors, such as $\mathrm{pH}$ and the type of salt specific ions proved to be the most important for determining the rate of environmental stress.

Differences occurred in the colony types of specific microbial groups between the two sites: samples from Zám reached the maximal variability at the $10 \mathrm{~g} \mathrm{l}^{-1}$ salt concentration, while samples from Nyírölapos decreased at the salt level. The ratio of adapted microbes and the tolerance limits were higher in case of Zám, where the salinity level and the stress is lower. This finding suggests that electric conductivity, $\mathrm{pH}$ level and types of salt specific ions influence the mechanism of adaptation and result in a great selection from the original microbial population. Somewhat similar results were reported in case of arbuscular mycorrhizal fungi and nitrogen fixing or salt tolerant bacteria under the increasing stress of heavy metal salts (BIRÓ et al., 1999; ZAHRAN, 1997; FÜZY et al., 2001). All results in this experiment suggest therefore, that the colony forming types and units of rhizosphere microbes increase at a certain level of salt concentrations. The same result was also found for some other biotic and abiotic stress factors. At higher levels of these limiting factors (salinity, heavy metals, drought, $\mathrm{pH}$ ), beyond certain optimal limits, however these parameters might be significantly reduced concomitant with the loss of function in the environment. Permanent monitoring of the microbial characteristics in the various soil-plant systems, may serve as early "warning signals" of the environmental stress preceding the irreversible changes. Microbial characteristics are sensitive indicators of the various stress conditions in soilplant systems. 


\section{Summary}

The abundance of some culturable soil microorganisms (bacteria and fungi) was examined at two Hungarian salt-affected soils of the Hortobagy region. In addition to the so-called "helper bacteria" (Pseudomonas sp., nitrogen fixers), which are mainly attached to the rhizoplane, the abundance of other microbial groups (total number of bacteria, micromycetes, Actinomycetes) were also assessed. A modified, selective plate dilution assay was used with increasing salt $(\mathrm{NaCl})$ concentrations (5-50 $\mathrm{g}^{-1}$ media), for assessing the salt tolerant ratio of specific microbial groups.

The type of main salt-specific ions differed at the two sites, resulting more or less stressed $\mathrm{pH}$ conditions in the rhizosphere of the most typical halophytes. At Zám mainly the chloride, at Nyírölapos, however mainly sulphate ions dominated in the samples (at an $80 \%$ level), which resulted in a more severe stress situation. Actinomycetes proved to be especially abundant in the salt affected soils examined. In almost all microbial groups, only the high in vitro concentration of salt $\left(50 \mathrm{~g} \mathrm{l}^{-1}\right)$ reduced the abundance and the colony types of microorganisms. Nitrogen fixers, however were affected at lower salt concentrations and were found to be the most sensitive group at both sites. Variability of the existing colony types of micromycetes was reduced significantly by increasing levels of salinity. Soil- and rhizo-biological characteristics proved to be sensitive indicators of soil quality and environmental conditions.

Key words: salt stress, culturable microbes, sensitivity, diversity

Present work was supported by the National Scientific Research Fund (OTKA T030235, T030941 projects) and the European Comission Fp5 (Mycorem project).

\section{References}

ANGERER, I. P. et al., 1998. Indicator microbes of chlorsulphuron addition detected by a simplified soil dilution method. Agrokémia és Talajtan. 47. 297-305.

BIRÓ, B. et al., 1999. Intensification of nodulation and nitrogen-fixing activity preceding the ,loss of function” by the long-term application of some toxic metal rates. In: Proc. of $5^{\text {th }}$ Intern. Conference on Biogeochemistry of Trace Elements (Eds.: WeNZEL, W. W.) 178-179. BOKU Univ. Vienna.

BIRÓ, B. et al., 2000. Interrelations between Azospirillum and Rhizobium nitrogenfixers and arbuscular mycorrhizal fungi in the rhizosphere of alfalfa in sterile, AM-free or normal soil conditions. Appl. Soil. Ecol. 15. 159-168.

FÜZY, A. et al., 2001. Colonisation of arbuscular mycorrhizal fungi on Festuca pseudovina and Matricaria chamomillae in two Hungarian salt-affected soils. Sci. Bulletin (North Univ. Baia Mare) C-XIV. 109-117. 
Hasegawa, P. M., Bressan, R. A. \& Hanada, A. K., 1986. Cellular mechanisms of salinity tolerance. Hort. Sci. 21. 1317-1324.

Horváth, S., 1980. Microbiological Practicum. (In Hungarian) Tankönyvkiadó. Budapest.

JUNIPER, S. \& ABBOTT, L., 1993. Vesicular-arbuscular mycorrhizas and soil salinity. Mycorrhiza 4. 45-57.

KING, E. O., WARD, M. K. \& RANEY, D. E., 1954. Two simple media for the demonstration of pycocianin and fluorescin. J. Lab. Clin. Med. 44. 301-306.

MARTIN, J. P., 1950. Use of acid rose bengal and streptomycin in the plate method for estimating soil fungi. Soil Sci. 69. 215-232.

Ruiz-Lozano, J. M., AzCón, R. \& Gómez, M., 1996. Allevation of salt stress by arbuscular-mycorrhizal Glomus species in Lactuca sativa plants. Physiol Plant. 98. 767-772.

SCHWARZ, M. \& GALE, J., 1984. Growth response to salinity at high levels of carbon dioxide. J Exp Bot. 35. 193-196.

SzABOLCS, I., 1998. Concepts, assessment and control of soils affected by salinization. Adv. GeoEcol. 31. 469-476.

SzABOlcs, I. \& VÁrallyay, Gy., 1978. Limiting factors of soil fertility in Hungary (In Hungarian). Agrokémia és Talajtan. 27. 181-202.

SzEGI, J., 1979. Soil Microbiological Manual (In Hungarian). Mezőgazdasági Kiadó. Budapest.

Williams, S. T. \& DAVIES, F. L., 1964. Use of antibiotics for selective isolation and enumeration of Actinomycetes in soil. J. Gen. Microbiol. 38. 251-261.

ZAHRAN, H. H., 1997. Diversity, adaptation and activity of the bacterial flora in saline environments. Biol. Fertil. Soil. 25. 211-223. 